DOI 10.32900/2312-8402-2019-121-33-44

УДК 639.3:615.32:615.38

\title{
THE ANTIBACTERIAL ACTIVITY OF THE ETHANOLIC LEAF EXTRACT OF FICUS VASTA FORSSK. (MORACEAE) AGAINST AEROMONAS SPP. STRAINS
}

\author{
Pękala-Safińska A., Ph.D. \\ Department of Fish Diseases, National Veterinary Research Institute, Pulawy, Poland \\ Tkachenko H., Doctor of Biological Sciences \\ Osadowski Z., Doctor of Biological Sciences \\ Institute of Biology and Environmental Protection, Pomeranian University in Słupsk, \\ Poland \\ Buyun L., Doctor of Biological Sciences \\ M. M. Gryshko National Botanic Garden, National Academy of Science of Ukraine, \\ Kyiv, Ukraine \\ Honcharenko V., Ph.D. \\ Ivan Franko Lviv National University, Lviv, Ukraine \\ Prokopiv A., Ph.D. \\ Botanic Garden of Ivan Franko Lviv National University, Lviv, Ukraine
}

The aim of the present study was to evaluate the antibacterial efficacy of ethanolic extracts from Ficus vasta Forssk against three Aeromonas strains (Aeromonas sobria, Aeromonas hydrophila, Aeromonas salmonicida subsp. salmonicida). The leaves of F. vasta were collected in M.M. Gryshko National Botanic Garden (NBG, Kyiv, Ukraine) and Botanic Garden of Ivan Franko Lviv National University (Lviv, Ukraine). Freshly collected leaves were weighed and homogenized in $96 \%$ ethanol (in proportion 1:10) at room temperature. Three Aeromonas strains: Aeromonas sobria (K825) and Aeromonas hydrophila (K886), as well as Aeromonas salmonicida subsp. salmonicida (St30), originated from freshwater fish species such as common carp (Cyprinus carpio L.) and rainbow trout (Oncorhynchus mykiss Walbaum), respectively, were isolated in Department of Fish Diseases, The National Veterinary Research Institute in Pulawy (Poland). Bacteria were collected from fish exhibiting clinical disorders. The largest inhibition zone diameter $(20.63 \pm 1.44 \mathrm{~mm})$ was obtained against Aeromonas sobria (K825) growth, while the smallest inhibition diameter $(13.38 \pm 0.42 \mathrm{~mm})$ and (13.0 $\pm 0.94 \mathrm{~mm})$ was obtained against Aeromonas hydrophila (K886) and Aeromonas salmonicida subsp. salmonicida (St30) strains, respectively. The ethanolic extract of F. vasta exhibited the intermediate activity against Aeromonas hydrophila and Aeromonas salmonicida subsp. salmonicida (St30), while Aeromonas sobria exhibited high susceptibility activity. The active compounds involved in the anti-Aeromonas activity have yet to be identified. The evaluation of the benefit/risk balance for the use of these plants in the treatment of Aeromonas-induced infections in the aquaculture could be better documented in in vivo study. A bioassay-guided fractionation study of the active extract of these plants is underway to identify the compound(s) responsible for this activity.

Keywords: Ficus vasta, Aeromonas sobria, Aeromonas hydrophila, Aeromonas salmonicida subsp. salmonicida, antimicrobial activity, disc diffusion technique, ethanolic extract.

Aeromonas species are ubiquitous and opportunistic bacterial pathogens that caused ulcerative dermatitis under stress conditions and inflicts severe losses on global 
fisheries and fish culture [11]. Aeromonas-induced virulence is multifaceted and involves surface-associated molecules, motility, biologically active extracellular products, and biofilm formation [7]. Infected fish frequently exhibit small pinpoint hemorrhages at the base of fins or on the skin, distended abdomens, and protruding eyes. Internal signs include fluid in the abdomen, swollen liver, and spleen, and distended and fluidfilled intestines. The disease can produce significant losses in the aquaculture industry because of reduced growth and unmarketable appearance of infected fish. When virulent strains of $A$. hydrophila become endemic in a fish population, introducing new fish into the water body without significant mortalities is difficult [20].

Recently, there is an increased frequency of multiple drug resistance in fish pathogenic microorganism due to indiscriminate use of commercial antimicrobial drugs commonly used to treat various diseases [25]. Consequently, the use of antibiotics and chemotherapeutics in aquaculture has received considerable attention because their accumulation both in the environment and in fish can be potentially risky to consumers and the environment [1]. Therefore, the use of natural products is considered as an alternative to control infections in aquaculture. Some plants are reported to have antimicrobial activity against several pathogenic bacteria. In this study, we tested the ethanolic extract obtained from Ficus vasta Forssk. leaves for antimicrobial activity against Aeromonas strains (A. sobria, A. hydrophila, A. salmonicida subsp. salmonicida).

Among 37 genera of Moraceae comprising 1050-1100 species in total, Ficus L. is the largest one with ca 750 species of tropical and subtropical distribution worldwide. Its characteristic features include the presence of waxy glands on vegetative plant parts, heterostyly, and prolonged protogyny, i.e., the anthesis of staminate flowers in already mature fruits $[5,10]$. Ficus trees have widely been used by humans over their history in a variety of industries and fields of activity. Virtually all parts of their body are utilized by local people in various medicinal practices to cure wounds, sores, stomach and eye problems, headaches and toothaches, and even tumors and cancer, etc. A number of species are known helpful in healing disorders of digestive and respiratory systems, parasitic infections, and also as painkillers, tonics, and ecbolics [16].

Ficus vasta Forssk. is a monoecious deciduous tree reaching up to $25 \mathrm{~m}$ in height, terrestrial, hemi-epiphytic or epilithic, with yellowish to whitish or brownish hirsute leafy twigs. The species is native to northeastern Africa and usually grows in relatively dry habitats or in riverine vegetation. Its leaves reach $8-35 \mathrm{~cm}$ in length and 4$25 \mathrm{~cm}$ in width; they are cordiform to suborbicular or ovate to reniform, coriaceous and densely puberulous to almost glabrous, with shortly acuminate to rounded apex, cordate base, and long petiole. The pedunculate puberulous syconia of subglobose to ellipsoid shape are born in pairs or solitary in the leaf axils or just below the leaves and reach 2 $2.5 \mathrm{~cm}$ in diameter, at maturity green with paler spots [6].

The leaves of $F$. vasta are traditionally used for the treatment of rheumatisms, pains and intestinal worms [22].

Recently, Taviano and co-workers (2018) evaluated the antioxidant and antimicrobial properties of a hydroalcoholic extract obtained from the leaves of $F$. vasta. In this study, the phenolic profile of the $F$. vasta leaf extract was characterized by HPLC-PDA/ESI-MS. The antioxidant properties were examined by different in vitro systems: DPPH test, reducing power and metal chelating activity assays. Moreover, the ability of the extract to inhibite Escherichia coli growth and survival from $\mathrm{H}_{2} \mathrm{O}_{2}$ induced oxidative stress was evaluated. By HPLC-PDA/ESI-MS analysis 12 compounds belonging to the groups of phenolic acids and flavonoids were identified. The extract exhibited bacteriostatic activity against almost all the bacteria tested (MICs: $250-62.5 \mu \mathrm{g} / \mathrm{mL}$ ) [27]. 


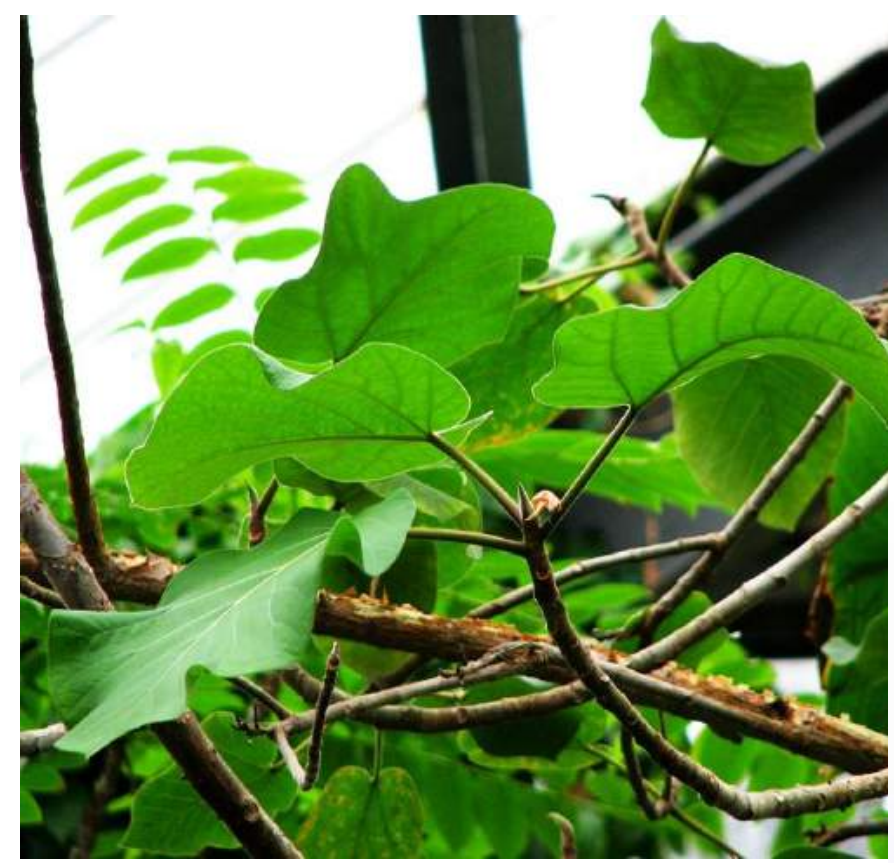

A

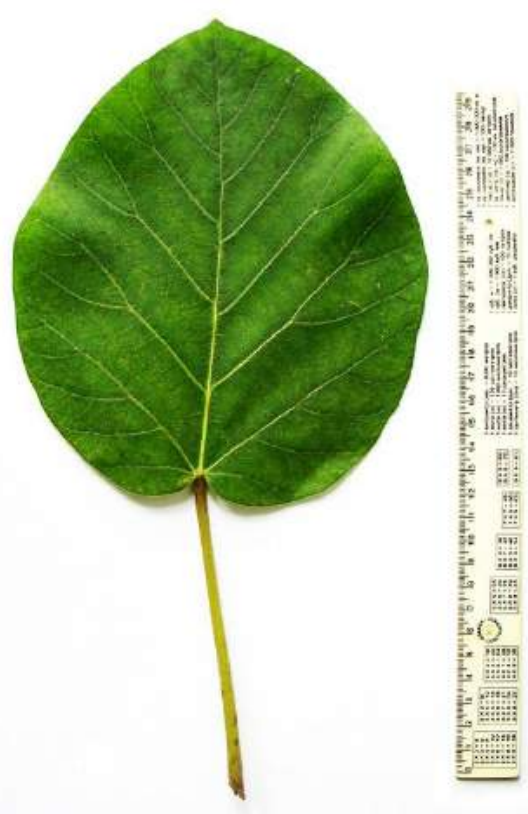

B

Fig. 1. Specimen of Ficus vasta, cultivated at Botanic Garden of Ivan Franko Lviv National University (Lviv, Ukraine) (A), and leaf sample of $F$. vasta (B).

Also, qualitative preliminary phytochemical analysis of $F$. vasta leaves, undertaken by Rashed with coauthors (2015), revealed the presence of carbohydrates, tannins, flavonoids, coumarins, and triterpenes [22]. Moreover, various phytoconstituents such as $\beta$-sitosterol, stigmasterol, lupeol, ursolic acid, and some flavonoids were isolated and identified from $F$. vasta aerial parts [23]. As for biological activities of $F$. vasta, very few studies have been carried out on the leaves of this species [19, 21].

We have reported already data on the antioxidant and antibacterial effects of extracts from various plant belonged to the Ficus genus [28-39]. Our current scientific project undertaken in the frame of cooperation programme between Institute of Biology and Environmental Protection (Pomeranian University in Slupsk, Poland), M. M. Gryshko National Botanic Gardens of National Academy of Sciences of Ukraine (Kyiv, Ukraine), and Ivan Franko Lviv National University (Lviv, Ukraine) directed to assessment of medicinal properties of tropical plants.

Therefore, the aim of the present study was to evaluate the antibacterial efficacy of ethanolic extracts derived from $F$. vasta against three Aeromonas strains (Aeromonas sobria, Aeromonas hydrophila, Aeromonas salmonicida subsp. salmonicida).

Materials and methods. Collection of plant material and preparing plant extract. The leaves of F. vasta were collected in M.M. Gryshko National Botanic Garden (NBG, Kyiv, Ukraine) and Botanic Garden of Ivan Franko Lviv National University (Lviv, Ukraine). The whole collections of tropical and subtropical plants both at NBG and Botanical Garden of Ivan Franko Lviv National University (including Ficus spp. plants) have the status of a National Heritage Collection of Ukraine. The species author abbreviations were followed by Brummitt and Powell (1992).

The sampled leaves were brought into the laboratory for antimicrobial studies. Then, freshly collected leaves were weighed and homogenized in $96 \%$ ethanol (in proportion 1:10) at room temperature, and centrifuged at 3,000 g for 5 minutes. Supernatants were stored at $-20^{\circ} \mathrm{C}$ in bottles protected with the laminated paper until required. 
Method of culturing pathological sample and identification method of the Aeromonas strains. Three Aeromonas strains: Aeromonas sobria (K825) and Aeromonas hydrophila (K886), as well as Aeromonas salmonicida subsp. salmonicida (St30), originated from freshwater fish species such as common carp (Cyprinys carpio L.) and rainbow trout (Oncorhynchus mykiss Walbaum), respectively, were isolated in Department of Fish Diseases, The National Veterinary Research Institute in Pulawy (Poland). Bacteria were collected from fish exhibiting clinical disorders. Each isolate was inoculated onto trypticase soy agar (TSA) (BioMérieux) and incubated at $27^{\circ} \mathrm{C} \pm 2^{\circ} \mathrm{C}$ for $24 \mathrm{~h}$. Pure colonies were used for biochemical identifications, according to the manufacturer's instructions, except the temperature of incubation, which was at $27^{\circ} \mathrm{C} \pm 1{ }^{\circ} \mathrm{C}$. The following identification systems were used in the study: API 20E, API 20NE, API 50CH (BioMérieux). Presumptive Aeromonas isolates were further identified to the species level by restriction analysis of $16 \mathrm{~S}$ rDNA genes amplified by polymerase chain reactions (PCR) [12].

Bacterial growth inhibition test of plant extracts by the disk diffusion method. Antimicrobial susceptibility of the tested Aeromonas isolates was performed by the Kirby-Bauer disc diffusion method according to the recommendations of the Clinical and Laboratory Standards Institute (CLSI, 2014) [9]. Each inoculum of bacteria in the density of $0.5 \mathrm{Mc}$ McFarland was cultured on Mueller-Hinton agar for $24 \mathrm{~h}$ at $28 \pm 2{ }^{\circ} \mathrm{C}$. Seven drugs representing different antimicrobial classes as quinolones, tetracyclines, sulphonamides, and phenicols were used. After incubation, the inhibition zones were measured. Interpretation criteria have been adopted from that available for Aeromonas salmonicida [8].

Statistical analysis. Statistical analysis of the data obtained was performed by employing the mean \pm standard error of the mean (S.E.M.). All variables were randomized according to the phytochemical activity of strains tested [40]. The following zone diameter criteria were used to assign susceptibility or resistance of bacteria to the phytochemicals tested: Susceptible $(\mathrm{S}) \geq 15 \mathrm{~mm}$, Intermediate $(\mathrm{I})=10-15 \mathrm{~mm}$, and Resistant $(\mathrm{R}) \leq 10 \mathrm{~mm}[18]$.

Results and discussion. The results of antimicrobial activity of an ethanolic extract derived from $F$. vasta leaves against three Aeromonas strains are presented in Fig. 2.

The largest inhibition zone diameter $(20.63 \pm 1.44 \mathrm{~mm})$ was obtained against Aeromonas sobria (K825) growth, while the smallest inhibition diameter $(13.38 \pm 0.42 \mathrm{~mm})$ and $(13.0 \pm 0.94 \mathrm{~mm})$ was obtained against Aeromonas hydrophila (K886) and Aeromonas salmonicida subsp. salmonicida (St30) strains, respectively (Fig. 2). The ethanolic extract of $F$. vasta exhibited the intermediate activity against Aeromonas hydrophila and Aeromonas salmonicida subsp. salmonicida (St30), while Aeromonas sobria exhibited high susceptibility activity.

Species of Aeromonas are short, Gram-negative, facultative anaerobic, nonspore-forming, motile bacilli with a single flagellum, and can ferment glucose with or without the production of gas. They are $0.3-1.0 \mu \mathrm{m}$ in diameter and $1.0-3.5 \mu \mathrm{m}$ in length. They occur ubiquitously and autochthonously in aquatic environments. The genus Aeromonas is within the family Aeromonadaceae, which comprises of 14 different species; among which, Aeromonas hydrophila is known to infect fish, reptiles, amphibians, and humans. Some diseases caused by A. hydrophila can spread from animals to humans and vice versa (Pachanawan et al., 2008). 


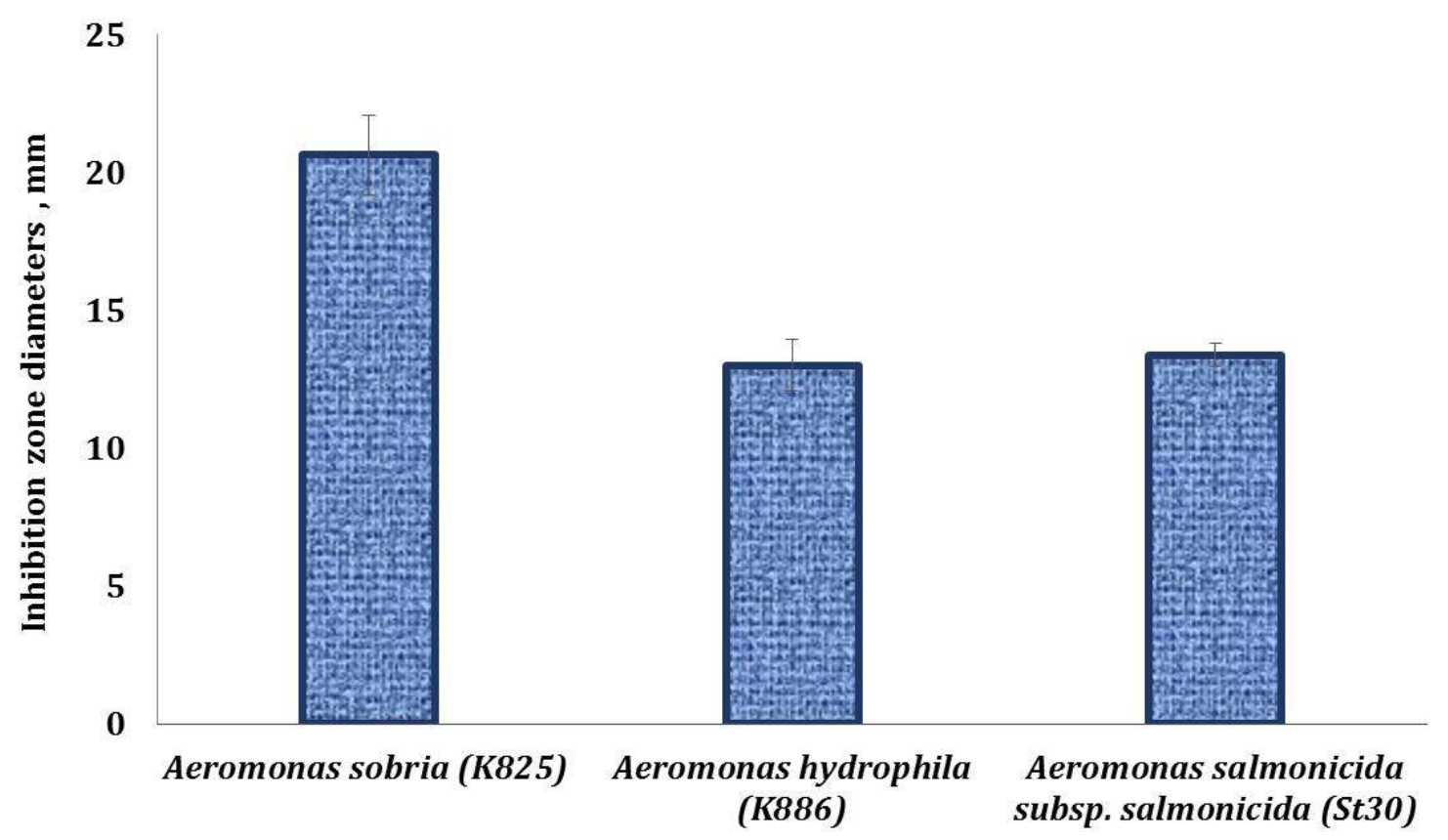

Fig. 2. The inhibition zone diameters of Aeromonas strains' growth $(1000 \mu \mathrm{L}$ inoculum) obtained from the ethanolic extract of $F$. vasta leaves $(M \pm m, n=8)$.

This study aimed to find a natural source, antimicrobial substance to replace antibiotics and chemotherapeutics for the treatment of Aeromonas-induced infections in fish aquaculture. According to our preliminary study and studies of other researchers $[24,26,28-39]$, it has been demonstrated that a number of ethanolic extracts derived from various Ficus species and their cultivars showed antibacterial activity against pathogenic isolates as well as antibiotic-resistant bacteria. The plant extracts of the above plant species can be used as a source which could yield alternative drugs to improve the treatment of infection caused by these Aeromonas strains.

The documented pharmacological activities of Ficus plants in relation to their use as antimicrobial preparations are summarized below. Al-Fatimi and coworkers (2007) investigated antioxidant, antimicrobial, and cytotoxic activities of dichloromethane, methanol and aqueous extracts of 30 plant species from Yemen. The extracts were tested against Gram-positive bacteria (Bacillus subtilis ATCC 6059, Micrococcus flavus SBUG 16, and Staphylococcus aureus ATCC 29213), Gram-negative bacteria (Escherichia coli ATCC 25922 and Pseudomonas aeruginosa ATCC 27853), Candida maltosa SBUG 17, and several opportunistic human fungal pathogens including yeasts (Candida albicans ATCC 90028 and C. krusei ATCC 90878) and hyphomycetes (Absidia corymbifera 100798, Aspergillus fumigatus 13550/99, and Trichophyton mentagrophytes 05/2004). S. aureus appeared the most susceptible among bacteria tested. Fruit extracts from F. vasta, the only Ficus species tested, generally were among the most active ones against bacteria, though they did not inhibit $E$. coli and fungal pathogens. The only methanol extract of $F$. vasta affected $S$. aureus, although with comparatively high inhibition efficacy: inhibition zone diameter of $18 \mathrm{~mm}$ and MIC of $50 \mu \mathrm{g} / \mathrm{ml}[2]$.

Aqueous extract of $F$. asperifolia Miq. stem bark assessed by Annan and Houghton (2008) for its activity against a number of bacteria species (Bacillus subtilis, E. coli, Micrococcus flavus, Pseudomonas aeruginosa, and Staphylococcus aureus) was found to have a generally weak antibacterial action. The minimal inhibition concentra- 
tion of the extract for P. aeruginosa was $512 \mu \mathrm{g} / \mathrm{ml}$, which was the highest value among the tested organisms [4].

Maregesi and co-workers (2008) screened $n$-hexane, methanol, and water extracts from 39 plant species of 22 families against a number of bacteria (Bacillus cereus ATCC 14579, Staphylococcus aureus ATCC 6538, Escherichia coli ATCC 8739, Pseudomonas aeruginosa ATCC 15442, Klebsiella pneumoniae ATCC 13883, and Salmonella typhimurium ATCC 13311), fungi (Aspergillus niger ATCC 16404 and Candida albicans ATCC 10231), and viruses (Herpes simplex Virus type 1, Vesicular Stomatitis Virus T2, Semliki forest A7, and Coxsackie B2). Gram-negative bacteria generally appeared hardly sensitive to the extracts tested, with MIC values of $1000 \mu \mathrm{g} / \mathrm{ml}$ and (mostly) higher. Stem bark extracts of F. sycomorus, the only Ficus species examined, were active against Gram-positive bacteria and fungi with MIC $1000 \mu \mathrm{g} / \mathrm{ml}$ and higher, while they showed comparatively strong antiviral activity [17].

Kuete and co-workers (2008) conducted a detailed study on antimicrobial activity of crude methanolic extracts and isolated flavonoids and isoflavonoids from F. chlamydocarpa root bark and $F$. cordata stem bark against 18 species of pathogenic microorganisms including mycobacteria, fungi, Gram-negative and Gram-positive bacteria. Some crude extracts and compounds were found active against all tested organisms with different level of inhibition. In respect to $P$. aeruginosa, $F$. chlamydocarpa crude extract was not active and $F$. cordata extract showed the weakest inhibition based on both disc diffusion and micro-dilution tests (with MIC 156,25 $\mu \mathrm{g} / \mathrm{ml}$ ). Particular compounds of these two species with generally the highest inhibitory activity, namely Luteolin (from $F$. chlamydocarpa) and Epiafzelechin (from $F$. cordata), similarly showed the weakest effect on $P$. aeruginosa at MICs 78,12 and $>625 \mu \mathrm{g} / \mathrm{ml}$ respectively. In general, $P$. aeruginosa demonstrated the lowest susceptibility among all organisms tested [15].

Further studies [14] focused on antimicrobial evaluation of methanolic extracts, hexane-ethyl acetate, and ethyl acetate-methanol extract fractions, and isolated compounds from stem bark of $F$. ovata Vahl., testing a range of microbe clinical isolates, including Gram-positive bacteria (methicillin-resistant Staphylococcus aureus LMP805, Streptococcus faecalis LMP806, and Bacillus cereus LMP716), Gram-negative bacteria ( $\beta$-lactamase positive Escherichia coli LMP701, ampicillin-resistant Klebsiella pneumoniae LMP803, carbenicillin-resistant Pseudomonas aeruginosa LMP804, chloramphenicol-resistant Salmonella typhi LMP706, and chloramphenicol-resistant Citrobacter freundii LMP802), and fungi (Candida albicans LMP709U and Microsporum audouinii LMP725D). The crude extracts and certain fractions and compounds were found active against all organisms tested. P. aeruginosa was most strongly inhibited (MIC $156 \mu \mathrm{g} / \mathrm{ml}$ ) by hexane $100 \%$ and Hex-EtOAc $25 \%$ fractions and two compounds of isoflavonoid and phenolic nature. The crude extract showed a MIC value of $312 \mu \mathrm{g} / \mathrm{ml}$ and other fractions and compounds produced MIC of 312 to $625 \mu \mathrm{g} / \mathrm{ml}$ against $P$. aeruginosa. Among all organisms tested, $P$. aeruginosa was moderately susceptible to the evaluated antimicrobial agents. In general, the most inhibitory-active compounds appeared to be 2'-hydroxyisoprunetin (isoflavonoid) and protocatechuic (phenolic) acid, affecting (nearly) all pathogens tested with relatively low MIC values. Antimicrobial activity of flavonoids and isoflavonoids was suggested to come from their ability to complex with the bacterial cell wall, resulting in the microbial growth inhibition [13, 14]. It should be also noted that in the study of Anani and co-workers (2000), evaluating plant antimicrobial activity by disc diffusion essay with the addition of UVA exposure, $F$. ovata root and bark methanolic extracts had no effect on the growth of $P$. aeruginosa [3]. 
Assessment of antimicrobial activity of the methanolic extract, its fractions and isolated compounds from $F$. polita Vahl. roots against a number of microbe strains (Candida albicans ATCC9002, Escherichia coli ATCC8739 and AG100, Klebsiella pneumoniae ATCC11296, Providencia smartii ATCC29916, Pseudomonas aeruginosa PA01, Salmonella typhi ATCC6539, and Staphylococcus aureus ATCC25922) revealed moderate susceptibility of $P$. aeruginosa [13]. Crude extract demonstrated relatively weak inhibition of this pathogen (MIC $128 \mu \mathrm{g} / \mathrm{ml}$ ). Hexane fraction of the extract and one isolated compound (namely, (E)-3,5,4'-trihydroxy-stilbene-3,5-O- $\beta$ - $D$ diglucopyranoside $\mathrm{C}_{26} \mathrm{H}_{32} \mathrm{O}_{13}$ ) showed the strongest inhibitory activity against $P$. aeruginosa with MIC $64 \mu \mathrm{g} / \mathrm{ml}$, the value equal to that of chloramphenicol used as reference antibiotic. Ethyl acetate and hexane-ethyl acetate fractions appeared ineffective [13].

In a study by Harikrishnan and Balasundaram (2008), the antimicrobial potency of aqueous and ethanolic decoction (individual extract) and concoction (mixed extract) of three common medicinal herbs, turmeric Curcuma longa, Tulsi plant Ocimum sanctum, and neem Azadirachta indica, against the A. hydrophila growth was evaluated. Among the decoctions, $A$. indica exhibited the most potent antibacterial property $(\mathrm{P}<$ $0.05)$ against $A$. hydrophila. Among the concoctions, both the aqueous and ethanolic triherbal extracts mixed in the ratio of 1:1:1 had higher antibacterial activity $(\mathrm{P}<0.05)$ than the other concoctions and decoctions [11].

Conclusions. The ethanolic extracts of Ficus vasta were found to exhibit a strong antibacterial growth inhibitory effect against three Aeromonas strains. The active compounds involved in the anti-Aeromonas activity have yet to be identified. The evaluation of the benefit/risk balance for the use of these plants in the treatment of Aeromonas-induced infections in the aquaculture could be better documented in in vivo study. A bioassay-guided fractionation study of the active extract of these plants is underway to identify the compound(s) responsible for this activity. Thus, the findings of this research contribute to an increase in knowledge about $F$. vasta, demonstrating the potential of $\boldsymbol{F}$. vasta leaves as a source of plant-derived antimicrobial compounds to be used in fisheries.

Acknowledgments. The study was supported by a grant from the International Visegrad Fund, and we thank them for financial assistance for our study.

\section{References}

1. Alderman, D. J., \& Hastings, T. S. (1998). Antibiotic use in aquaculture: development of antibiotic resistance-potential for consumer health risks. Int. J. Food Sci. Technol., 33. 139-155.

2. Al-Fatimi, M., \& Wurster, M., Schröder, G., Lindequist, U. (2007). Antioxidant, antimicrobial and cytotoxic activities of selected medicinal plants from Yemen. Journal of Ethnopharmacology, 111, 657-666.

3. Anani, K., \& Hudson, J.B., de Souza, C., Akpagana, K., Tower, G. H. N., Amason, J.T., Gbeassor, M. (2000). Investigation of medicinal plants of Togo for antiviral and antimicrobial activities. Pharmaceutical Biology, 38(1), 40-45.

4. Annan, K., \& Houghton, P. J. (2008). Antibacterial, antioxidant and fibroblast growth stimulation of aqueous extracts of Ficus asperifolia Miq. and Gossypium arboreum L., wound-healing plants of Ghana. Journal of Ethnopharmacology,. 119, 141144.

5. Berg, C. C., \& Corner, E. J. H. (2005). Moraceae (Ficus). Noteboom H.P. (ed.) Flora Malesiana, Ser. 1, Vol. 17, Part 2. National Herbarium Nederland, Leiden, pp. 1-730. 
6. Berg, C. C., \& Wiebes, J. T. (1992). African fig trees and fig wasps. Koninklijke Nederlandse Akademie van Wetenschappen, Verhandelingen Afdeling Natuurkunde, $2^{\text {de }}$ reeks, deel 89. North-Holland, Amsterdam.

7. Chenia, H. Y., \& Duma S. (2017). Characterization of virulence, cell surface characteristics and biofilm-forming ability of Aeromonas spp. isolates from fish and seawater. J. Fish Dis., 40(3), 339-350.

8. Clinical and Laboratory Standards Institute (CLSI) (2006). VET03-A Methods for antimicrobial disk susceptibility testing of bacteria isolated from aquatic animals, Approved Guideline. 26, 23, Wayne, PA, USA. P. 43.

9. Clinical and Laboratory Standards Institute (CLSI) (2014). VET03-/VET04S2 Performance standards for antimicrobial susceptibility testing of bacteria isolated from aquatic animals, Second Informational Supplement. 34, 15, Wayne, PA, USA. P. 31

10. Cook, J. M., \& Rasplus, J.-Y. (2003). Mutualists with attitude: coevolving fig wasps and figs. Trends in Ecology \& Evolution, 18(5), 241-248.

11. Harikrishnan, R., Balasundaram, C. 2008. In vitro and in vivo studies of the use of some medicinal herbals against the pathogen Aeromonas hydrophila in goldfish. J. Aquat.Anim. Health, 20(3), 165-176.

12. Kozińska, A. (2007). Dominant pathogenic species of mesophilic aeromonads isolated from diseased and healthy fish cultured in Poland. Journal of Fish Diseases, 30, 293-301.

13. Kuete, V., \& Kamga, J., Sandjo, L.P., Ngameni, B., Poumale, H. M. P., Ambassa, P., Ngadjui, B. T. (2011). Antimicrobial activities of the methanol extract, fractions and compounds from Ficus polita Vahl. (Moraceae). BMC Complementary and Alternative Medicine, 11, 6.

14. Kuete, V., Nana, F., Ngameni, B., Mbaveng, A. T., Keumedjio, F., Ngadjui, B.T. (2009). Antimicrobial activity of the crude extract, fractions and compounds from stem bark of Ficus ovata (Moraceae). Journal of Ethnopharmacology, 124, 556-561.

15. Kuete, V., \& Ngameni, B., Simo, C. C. F., Tankeu, R. K., Ngadjui, B. T., Meyer, J. J. M., Lall, N., Kuiate, J. R. (2008). Antimicrobial activity of the crude extracts and compounds from Ficus shlamydocarpa and Ficus cordata (Moraceae). Journal of Ethnopharmacology, 120, 17-24.

16. Lansky, E. P., \& Paavilainen, H. M. (2011). Figs: the genus Ficus. Hardman R. (ed.) Traditional herbal medicines for modern times, 9. CRC Press, Boca Raton, pp. $1-357$.

17. Maregesi, S. M., \& Pieters, L., Ngassapa, O. D., Apers, S., Vingerhoets, R., Cos, P., Berghe, D. A. V., Vlietinck, A. J. (2008). Screening of some Tanzanian medicinal plants from Bunda district for antibacterial, antifungal and antiviral activities. Journal of Ethnopharmacology, 119, 58-66.

18. Okoth, D. A., \& Chenia, H. Y., Koorbanally, N. A. (2013). Antibacterial and antioxidant activities of flavonoids from Lannea alata (Engl.) Engl. (Anacardiaceae). Phytochem. Lett., 6, 476-481.

19. Osman, M. E., \& Yassen, H. H., Deng, J. D., Mustafa, R. O., Hussein, S. M. (2014). General phytochemical screening and antioxidant activity of some Sudanese medicinal plants. J. Forest Prod. Ind., 3(6), 292-295.

20. Pachanawan, A., \& Phumkhachorn, P., Rattanachaikunsopon, P. (2008). Potential of Psidium guajava supplemented fish diets in controlling Aeromonas hydrophila infection in tilapia (Oreochromis niloticus). J. Biosci. Bioeng., 106(5), 419-424. 
21. Raju, N. J., \& Yesuf, E. A., Bekele, M., Wabe, N. T. 2011. Investigation of in vitro anthelmintic activity of Ficus vasta leaves. Asian J. Pharm. Biol. Res., 1(4), 454-458.

22. Rashed, K., \& Anthonissen, R., Cappoen, D., Verschaeve, L. (2015). Phytochemical composition and potential genotoxic effects of important Egyptian medicinal plants. Phcog. Commn., 5(3), 207-216.

23. Rashed, K., \& Ono, L. (2013). Evaluation of cytotoxicity, anti-herpes simplex virus type 1 (HSV-1) and antibacterial activities of Ficus vasta and phytoconstituents. Int. Curr. Pharm. J., 3(1), 211-218.

24. Salem, M. Z. M., \& Salem, A. Z. M., Camacho, L. M., Ali, H. M. (2013). Antimicrobial activities and phytochemical composition of extracts of Ficus species: An over view. Afr. J. Microbiol. Res., 7(33), 4207-4219.

25. Schmidt, A. S., \& Bruun, M. S., Dalsgaard, I., Pedersen, K., Larsen, J. L. (2000). Occurrence of antimicrobial resistance in fish-pathogenic and environmental bacteria associated with four Danish rainbow trout farms. Applied and environmental microbiology, 66(11), 4908-4915.

26. Sirisha, N., \& Sreenivasulu, M., Sangeeta, K., Chetty, C. M. (2010). Antioxidant properties of Ficus species, a review. Int. J. Pharma Techn. Res., 4, 2174 2182.

27. Taviano, M. F., \& Rashed, K., Filocamo, A. et al. (2018). Phenolic profile and biological properties of the leaves of Ficus vasta Forssk. (Moraceae) growing in Egypt. BMC Complement. Altern. Med., 18(1), 161.

28. Tkachenko, H., \& Buyun, L., Kasiyan, O., Terech-Majewska, E., Honcharenko, V., Prokopiv, A., Osadowski, Z. (2018). Preliminary in vitro screening of antibacterial activity of leaf extract from Ficus natalensis subsp. natalensis Hochst. (Moraceae) against fish pathogens. Agrobiodiversity for Improving Nutrition, Health and Life Quality, (2), 170-183.

29. Tkachenko, H., \& Buyun, L., Kasiyan, O., Terech-Majewska, E., Osadowski, Z. (2018). The antibacterial activity of the ethanolic leaf extract of Ficus pumila L. (Moraceae) against fish bacterial pathogens. Научные труды Дальрыбвтуза (Scientific Journal of Dalrybvtuz), 45(2), 20-30.

30. Tkachenko, H., \& Buyun, L., Osadowski, Z., Honcharenko, V., Prokopiv, A. (2017). The antimicrobial efficacy of ethanolic extract obtained from Ficus benghalensis L. (Moraceae) leaves. Agrobiodiversity for Improving Nutrition, Health and Life Quality, (1), 438-445.

31. Tkachenko, H., \& Buyun, L., Osadowski, Z., Prokopiv, A., Honcharenko, V. (2017). Studies on antibacterial activity of Ficus binnendijkii Miq. (Moraceae) leaf extract. Visnyk Kyyivs'koho natsional'noho universytetu imeni Tarasa Shevchenka (Introduktsiya ta zberezhennya roslynnoho riznomanittya) [Bulletin of the Taras Shevchenko National University of Kyiv (Introduction and Conservation of Plant Diversity)], 1(35): $57-61$.

32. Tkachenko, H., \& Buyun, L., Osadowski, Z., Terech-Majewska, E., Honcharenko, V., Prokopiv, A. (2017). Comparative study of antimicrobial efficacy of the ethanolic leaf extract of Ficus benghalensis L. (Moraceae) against bacterial fish pathogens. Stupskie Prace Biologiczne, 14, 229-252.

33. Tkachenko, H., \& Buyun, L., Terech-Majewska, E., Honcharenko, V., Prokopiv, A., Osadowski, Z. (2019). Preliminary in vitro screening of the antibacterial activity of leaf extracts from various Ficus species (Moraceae) against Yersinia ruckeri. Fish. Aquat. Life, 27, 15-26. 
34. Tkachenko, H., \& Buyun, L., Terech-Majewska, E., Osadowski, Z. (2016). Antibacterial activity of ethanolic leaf extracts obtained from various Ficus species (Moraceae) against the fish pathogen, Citrobacter freundii. Baltic Coastal Zone - Journal of Ecology and Protection of the Coastline, 20, 117-136.

35. Tkachenko, H., \& Buyun, L., Terech-Majewska, E., Osadowski, Z. (2016). In vitro antimicrobial activity of ethanolic extracts obtained from Ficus spp. leaves against the fish pathogen Aeromonas hydrophila. Arch. Pol. Fish., 24, 219-230.

36. Tkachenko, H., \& Buyun, L., Terech-Majewska, E., Osadowski, Z. (2017). Antibacterial screening of ethanolic extracts obtained from leaves of various Ficus species (Moraceae) against Citrobacter freundii. Tpydbl BHИРО (Trudy VNIRO), 167, 138-149.

37. Tkachenko, H., \& Buyun, L., Terech-Majewska, E., Osadowski, Z. (2017). Screening for antimicrobial activities of the ethanolic extract derived from Ficus hispida L.f. leaves (Moraceae) against fish pathogens. Научные труды Дальрыьвтуза (Scientific Journal of DALRYBVTUZ), 41, 56-64.

38. Tkachenko, H., \& Buyun, L., Terech-Majewska, E., Osadowski, Z., Sosnovskyi, Y., Honcharenko, V., Prokopiv, A. (2016). The antimicrobial activity of some ethanolic extracts obtained from Ficus spp. leaves against Aeromonas hydrophila. Tруды ВНИРО (Trudy VNIRO), 162, 172-183.

39. Tkachenko, H., \& Buyun, L., Terech-Majewska, E., Osadowski, Z., Sosnovskyi, Y., Honcharenko, V., Prokopiv, A. (2016). In vitro antibacterial efficacy of various ethanolic extracts obtained from Ficus spp. leaves against the fish pathogen, Pseudomonas fluorescens. In: Globalisation and regional environment protection. The technique, technology, ecology. Eds Tadeusz Noch, Wioleta Mikołajczewska, Alicja Wesołowska. Gdańsk, Gdańsk High School Publ., 2016, 265-286.

40. Zar, J. H. (1999). Biostatistical Analysis. $4^{\text {th }}$ ed., Prentice-Hall Inc., Englewood Cliffs, New Jersey

АНТИМИКРОБНАЯ ЭФФЕКТИВНОСТЬ ЭТАНОЛЬНОГО ЭКСТРАКТА, ПОЛУЧЕННОГО ИЗ ЛИСТЬЕВ FICUS VASTA FORSSK. (MORACEAE), OTНОСИТЕЛЬНО ШТАММОВ АЕROMONAS SPP.

Пенкала-Сафинская А., Отдел заболеваний рыб Национального научноисследовательского ветеринаринарного института в Пулавах (Польша);

Ткаченко Г., Осадовский 3., Институт биологии и охраны окружающей средь Поморской Академии в Слупске (Слупск, Польша);

Буюн Л., Национальный ботанический сад им. Н. Н. Гришко НАН Украиньљ (Киев, Украина);

Гончаренко В., Львовский национальный университет имени Ивана Франко (Львов, Украина);

Прокопив А., Ботанический сад Львовского начионального университета имени Ивана Франко (Львов, Украина)

Цель данного исследования состояла в определении антимикробной активности этанольного экстракта листьев Ficus vasta Forssk. в отношении трех uтаммов Aeromonas (Aeromonas sobria, Aeromonas hydrophila, Aeromonas salmonicida subsp. salmonicida). Образць листьев F. vasta были собраны в Нащиональном ботаническом саду им. Н. Н. Гришко (НБС, Киев, Украина) и Ботаническом саду Львовского наџионального университета имени Ивана Франко (Львов, Украина). Свежесобранные листья взвешивали и гомогенизировали в 96 \%-ном этаноле (в пропориии 1:10) при комнатной температуре. Три итамма Aеromonas: Aeromonas sobria (K825), Aeromonas hydrophila (K886), a maкже Aer- 
omonas salmonicida subsp. salmonicida (St30), выделенные из видов пресноводных рыб, таких как карп обыкновенный (Cурrinus сагріо L.) и радужная форель (Oncorhynchus mykiss Walbaum), соответственно, были получены в Отделе заболеваний рыб Национального научно-исследовательского института ветеринарии в Пулавах (Польша). Материаль для бактериологических исследований были взяты от рыб с видимыми клиническими проявлениями заболевания. Наибольший диа-

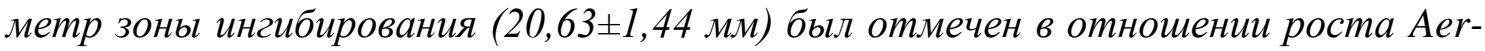
omonas sobria (K825), в то время, как наименьший диаметр зоны ингибирования

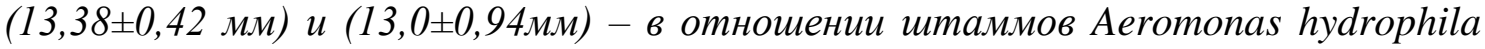
(K886) и Aeromonas salmonicida subsp. salmonicida (St30), соответственно. Этанольный экстракт листьев F. vasta оказывал умеренную активность в отношении Aeromonas hydrophila u Aeromonas salmonicida subsp. salmonicida (St30); в свою очередь, для Aeromonas sobria была характерна высокая степень восприимчивости к действию экстракта исследуемого растения. В дальнейшем, при определении состава веществ, оказывающих антимикробную активность в отномении Aeromonas, должен быть предпринят фитохимический скрининг листьев F. vasta. Для оценки баланса польза/риск при использовании этих растений в лечении Aeromonаs-индуцированных инфекций в аквакультуре должно быть осуществлено исследование in vivo. В настоящее время проводится фракционирование, опирающееся на результаты определения биоактивности соединений, содержащчихся в экстрактах, для идентификации соединения(й), ответственных за эту активность.

Ключевые слова: Ficus vasta, Aeromonas sobria, Aeromonas hydrophila, Aeromonas salmonicida subsp. salmonicida, антимикробная активность, дискодиффузионный метод Байера-Кирби, этанольный экстракт

\section{АНТИМІКРОБНА ЕФЕКТИВНІСТЬ ЕТАНОЛЬНОГО ЕКСТРАКТУ,} OTРИМАНОГО IЗ ЛИСТЯ FICUS VASTA FORSSK. (MORACEAE) ЩОДО UTAMIB AEROMONAS SPP.

Пенкала-Сафінська А., Відділ захворювань риб Національного науководослідного ветеринарного інституту в Пулавах (Польщза);

Ткаченко Г., Осадовський 3., Інститут біології та охорони навколишнього середовища Поморської Академї в Слупську (Слупськ, Польща);

Буюн Л., Національний ботанічний сад ім. М. М. Гришка НАН Украӥни (Київ, Україна);

Гончаренко В., Львівський начіональний університет ім. Івана Франка (Львів, Україна);

Прокопів А., Ботанічний сад Львівського національного університету імені Івана Франка (Львів, Україна)

Мета даного дослідження полягала у визначенні антимікробної активності етанольного екстракту листя Ficus vasta Forssk. щодо трьох итамів Aeromonas (Aeromonas sobria, Aeromonas hydrophila, Aeromonas salmonicida subsp. salmonicida). Зразки листя F. vasta були зібрані в Начіональному ботанічному саду імені М.М. Гришко (НБС, Киї, Україна) і Ботанічному саду Львівського національного університету імені Івана Франка (Львів, Украӥна). Свіжозібране листя зважували і гомогенізували в 96 \%-ному етанолі (в пропориії 1:10) при кімнатній meмnepamypi. Три штами Aeromonas: Aeromonas sobria (K825), Aeromonas hydrophila (K886), a також Aeromonas salmonicida subsp. salmonicida (St30), видiлені з видів прісноводних риб, таких як короп звичайний (Cyprinus carpio L.) та райдужна форель (Oncorhynchus mykiss Walbaum), відповідно, були отримані у 
Відділі захворювань риб Національного науково-дослідного ветеринарного інституту в Пулавах (Польща). Матеріали для бактеріологічних досліджень були взяті від риб з видимими клінічними проявами захворювання. Найбільший діаметр зони пригнічення $(20,63 \pm 1,44$ мм) був відзначений щзодо росту Aeromonas sobria (K825), в той час, як найменший діаметр зони пригнічення $(13,38 \pm 0,42$ мм) $i$ (13,0 \pm 0,94мм) - відносно штамів Aeromonas hydrophila (K886) i Aeromonas salmonicida subsp. salmonicida (St30), відповідно. Етанольний екстракт листя F. vasta проявив помірну активність щчодо Aeromonas hydrophila $i$ Aeromonas salmonicida subsp. salmonicida (St30); в свою чергу, для Aeromonas sobria була характерна висока ступінь чутливості щьодо дї екстракту досліджуваної рослини. Надалі, при визначенні складу речовин, щзо надають антимікробну активність відносно Aeromonas, має бути зроблений фітохімічний скринінг листя F. vasta. Для оиінки балансу користь / ризик при використанні изих рослин в лікуванні Aeromonas-індукованих інфекиій в аквакультурі має бути здійснено дослідження in vivo. В даний час проводиться фракціонування, щуо спирається на результати визначення біоактивності сполук, щзо містяться в екстрактах, для ідентифікації сполук, відповідальних за ию активність.

Ключові слова: Ficus vasta, Aeromonas sobria, Aeromonas hydrophila, Aeromonas salmonicida subsp. salmonicida, антимікробна активність, дискодифузійний метод Байєра-Кірбі, етанольний екстракт

DOI 10.32900/2312-8402-2019-121-44-52

УДК 636.92.084.085.55:591.11

\title{
БІОХІМІЧНІ ПОКАЗНИКИ КРОВІ КРОЛІВ М'ЯСНОГО НАПРЯМУ ПРОДУКТИВНОСТІ ЗА ЗГОДОВУВАННЯ МАЛОКОМПОНЕНТНИХ КОМБІКОРМІВ
}

\author{
Аксьонов С. О. ${ }^{1}$ м. н. с. \\ Інститут тваринництва НААН України
}

В статті висвітлено результати експериментальних досліджень біохімічних показників крові кролів м'ясного напряму продуктивності, вирощених за різних умов годівлі.

Піддослідному молодняку згодовували малокомпонентні комбікорми, з різною структурою та співвідношенням компонентів. У розрізі трьох дослідних груп використовували екструдовані зернові компоненти, розбіжності між групами забезпечували шляхом зменшення частки ячменю з 70 \% до $50 \%$ за масою та відповідно збільшенням частки зерна сої. Вміст сінного борошна в раціонах усіх порівнювальних груп становив $10 \%$.

Встановлено, щзо біохімічні показники крові кролів дослідних груп знаходилися у межах фізіологічної норми.

Покращення рівня і повноцінності протеїнового живлення тварин, за рахунок підвищення частки сої у складі комбікорму кролів II і III груп на 10 і 20 \%, сприяло підвищенню загального рівня білка у сироватці крові. Так, у кролів ІІІ дос-

\footnotetext{
${ }^{1}$ Науковий керівник - д. с.-г. н., професор Помітун I. А.
} 